\title{
Development of Membrane Properties in Taste Cells of Fungiform Papillae: Functional Evidence for Early Presence of Amiloride- Sensitive Sodium Channels
}

\author{
A. H. Kossel, M. McPheeters, W. Lin, and S. C. Kinnamon \\ Department of Anatomy and Neurobiology, Colorado State University, Fort Collins, Colorado 80521, and Rocky Mountain \\ Taste and Smell Center, University of Colorado Health Sciences Center, Denver, Colorado 80262
}

\begin{abstract}
Behavioral and physiological studies have demonstrated a reduced sensitivity to several taste stimuli early in development. It has been suggested that this reduced sensitivity results from a late maturation of underlying transduction mechanisms. Little is known, however, about maturation of membrane properties of taste cells early in development. We have obtained wholecell recordings from single fungiform taste cells of rat pups to examine the development of the $\mathrm{NaCl}$ transduction system. Although taste buds undergo a considerable increase in size during development, membrane capacitance measurements revealed no change in membrane surface area of individual taste cells, suggesting that the increase in size results from an increase in the total number of cells per bud. Whole-cell recordings showed that taste cells from very young pups [postnatal day 2 (PND2)] already possessed voltage-activated $\mathrm{Na}^{+}$and $\mathrm{K}^{+}$currents with no apparent differences in size or kinetics compared with adults. Surprisingly, amiloride-sensitive $\mathrm{Na}^{+}$ responses, important for $\mathrm{Na}^{+}$transduction, were found as early as PND2. The magnitude of responses to amiloride and the
\end{abstract}

percentage of amiloride-sensitive cells remained the same throughout all age groups. Furthermore, the similarity of amiloride inhibition constants suggested that the channel in neonates is the same channel that is expressed in adult taste buds. Our results indicate that taste cells at PND2 already have acquired the transduction elements necessary for signaling $\mathrm{NaCl}$ responses to the afferent nerve. We hypothesize that complete functionality of the salt taste transduction system, however, may not be reached until amiloride-sensitive $\mathrm{Na}^{+}$ channels become selectively localized at the apical membrane. This would explain previous studies indicating that amiloride sensitivity cannot be detected before PND12 in the intact tongue. Apical clustering of channels along with the opening of the taste pore and an increase in the total number of taste cells per bud likely constitute additional important steps toward a fully functional sensory system.

Key words: development; membrane properties; whole-cell recording; fungiform taste receptor cells; amiloride-sensitive sodium channels; taste pore
An important step in the functional development of sensory systems is the differentiation and maturation of the sensory epithelium. In addition to the development of the primary sensory cells, maturation of the mammalian taste system involves many steps that lead to functionally important structures in the taste epithelium. These include formation of microvilli, tight junctions, and the emergence of taste pores. Regarding the development and maturation of taste cells, the emergence of membrane properties necessary for the transduction of different taste stimuli and the ability to relay signals to the afferent nerve are important steps (Hill and Almi, 1980; Hill et al., 1982; Roper, 1983). Changes in response properties that occur during development have obvious repercussions on the functionality of the taste system. In addition, these changes may provide insights into the regulation of transduction mechanisms within taste cells as well as the regulation of other cellular processes, such as the polarization of the taste cell membrane. Because taste cells go through a developmental cycle throughout their lifetimes, studies of early

Received Aug. 12, 1997; revised Sept. 26, 1997; accepted Sept. 30, 1997.

This work was supported by National Institutes of Health Grants DC00766 and DC00244. We thank Cindy Church and Daniel Harris for participation in early phases of this study and Dr. L. Stone for helpful comments on this manuscript.

Correspondence should be addressed to Dr. Sue C. Kinnamon, Department of Anatomy and Neurobiology, Colorado State University, Fort Collins, CO 80523.

Dr. Kossel's present address: Max-Planck Institut for Psychiatry, Am Klopferspitz 18A, Muenchen-Martinsried 82152, Germany.

Copyright (C) 1997 Society for Neuroscience $0270-6474 / 97 / 179634-08 \$ 05.00 / 0$ development may also provide an important model for some aspects of taste cell turnover occurring in mature animals.

Previous studies have used behavioral paradigms and wholenerve recordings from chorda tympani fibers to examine the development of the different taste modalities (Hill and Almi, 1980; Ferrell et al., 1981; Hill et al., 1982; Moe, 1986; Bernstein and Courtney, 1987; Formaker and Hill, 1990; Sollars and Bernstein, 1994). These studies provided evidence that responsiveness to salt, bitter, sour, and sweet stimuli increases significantly during the first postnatal weeks in many species. The development of salt taste has been studied most extensively (Hill and Mistretta, 1990). Sensitivity to $\mathrm{NaCl}$ increases dramatically during the first 3 postnatal weeks and continues to increase thereafter (Hill and Mistretta, 1990). In contrast, the response to $\mathrm{NH}_{4} \mathrm{Cl}$ remains constant, which suggests that the integrity of nerve fibers and their associated synapses remains unchanged.

In adult rats, the primary mechanism for $\mathrm{NaCl}$ transduction is the amiloride-sensitive $\mathrm{Na}^{+}$channel. Passive influx of $\mathrm{Na}^{+}$ through this channel leads to membrane depolarization, activation of voltage-gated $\mathrm{Na}^{+}$and $\mathrm{K}^{+}$channels, $\mathrm{Ca}^{2+}$ influx, and transmitter release onto gustatory afferent neurons (Roper, 1983; Kinnamon and Roper, 1988). The importance of the amiloridesensitive $\mathrm{Na}^{+}$channel in $\mathrm{Na}^{+}$transduction was first demonstrated by afferent nerve recordings, which show that the chorda tympani response to $\mathrm{NaCl}$ is amiloride-sensitive (Heck et al., 1984). In contrast, the response to $\mathrm{NaCl}$ in neonatal rats is 
completely amiloride-insensitive before postnatal days 8-14 (PND8-14) (Hill and Bour, 1985; Hill, 1987; Sollars and Bernstein, 1994). These data suggested that amiloride-sensitive $\mathrm{Na}^{+}$ channels may not be present in early neonates. Recent immunohistochemical studies, however, have shown that the channel protein is expressed in fungiform taste cells shortly after birth (Stewart and Hill, 1992; Stewart et al., 1995). The presence of immunoreactivity does not indicate the functional status of the channels within the membrane. In fact, amiloride-sensitive $\mathrm{Na}^{+}$ channels have been detected immunocytochemically in circumvallate taste cells (Simon et al., 1993; Li et al., 1994; Lin et al., 1997; Lindemann et al., 1997), which do not show any functional amiloride sensitivity even in the adult rat (Doolin and Gilbertson, 1996). Thus, physiological studies are necessary to demonstrate functionality of the proteins identified by immunocytochemistry.

In this paper, we provide functional evidence for the expression of mature amiloride-sensitive $\mathrm{Na}^{+}$channels as early as PND2. In addition, voltage-gated $\mathrm{Na}^{+}$and $\mathrm{K}^{+}$channels are present at PND2, suggesting that these taste cells have the capacity to signal taste responses to the afferent nerve. Our data suggest that the lack of amiloride sensitivity observed in afferent nerve recordings of young postnatal rats most likely reflects the lack of an open taste pore and the absence of clustered amiloridesensitive $\mathrm{Na}^{+}$channels in the apical membrane of taste cells. Preliminary accounts of these data have been published in abstract form (McPheeters et al., 1994; Kinnamon et al., 1995).

\section{MATERIALS AND METHODS}

Taste bud isolation. Rat pups (Sprague Dawley) of different ages ranging from PND0 to adult (PND30) were used in this study. Taste buds were isolated as described previously (Gilbertson et al., 1993). Pups were decapitated, and the tongues were excised and washed in cold Tyrodes solution (in mM): $\mathrm{NaCl} 140, \mathrm{KCl} 5, \mathrm{CaCl}_{2} 1, \mathrm{MgCl}_{2} 1$, HEPES 10, glucose 10 , pyruvate $10, \mathrm{pH} 7.4$. Tongues were injected with $0.3-0.6 \mathrm{ml}$ of an enzyme mixture containing $3 \mathrm{mg}$ of Dispase (Boehringer Mannheim), $1 \mathrm{mg}$ of Trypsin Inhibitor (Sigma), and $0.7 \mathrm{mg}$ of Collagenase (Boehringer type 130U,180U) dissolved in Tyrodes solution. After incubation for 30-90 min in oxygenated Tyrodes solution, the epithelium was peeled off, transferred to a SYLGARD-covered Petri dish, and pinned down. Tongues of young animals (PND2-10) usually required longer incubation times (60-90 min). After an additional $40 \mathrm{~min}$ in calcium-free Tyrodes solution with $1 \mathrm{~mm}$ BAPTA, the medium was switched to regular Tyrodes solution. A pulled glass pipette was used to remove individual taste buds with gentle suction. Individual taste buds were plated onto coverslips coated with Cell Tak (Collaborative Research).

Electrophysiology. Patch pipettes were pulled from hematocrit tubes (Scientific Products) using a Narashige puller (Narashige PB7). Electrode shafts were coated with dental periphery wax to minimize electrode capacitance. The intracellular recording solution contained (in $\mathrm{mM}$ ): $\mathrm{KCl}$ $140, \mathrm{MgCl}_{2} 2$, HEPES 10, EGTA 11, $\mathrm{CaCl}_{2} 1$, ATP 1, GTP 0.4, pH 7.2. Tip resistances were 3-8 $\mathrm{M} \Omega$ when filled with intracellular saline. Seal resistances ranged between 1 and $10 \mathrm{G} \Omega$. Whole-cell membrane currents were recorded using an Axopatch 1B amplifier (Axon Instruments). Cells were voltage-clamped to $-80 \mathrm{mV}$, and holding current was recorded in response to bath application of amiloride and $\mathrm{Na}^{+}$replacement with NMDG ( $N$-methyl-D-glucamine). Signals were recorded on a strip chart recorder (Linear) as well as on videotape using a VCR (JVC) and subsequently analyzed. Voltage-gated currents were recorded on a computer (Digital Equipment Corporation) in response to $10 \mathrm{mV}$ voltage steps from -80 to $+60 \mathrm{mV}$. For inward currents, amplitude and timeto-half-amplitude $\left(T_{1 / 2}\right)$ were measured at the voltage step eliciting the peak current. For outward currents, these parameters were measured at $+60 \mathrm{mV}$. Membrane capacitance and cell surface area were calculated by dividing the integrated membrane transients by the amplitude of a $10 \mathrm{mV}$ hyperpolarizing step and assuming a specific membrane capacitance of 1 $\mu \mathrm{F} / \mathrm{cm}^{2}$. NMDG solutions were made by replacing $\mathrm{NaCl}$ with $140 \mathrm{~mm}$ NMDG in the Tyrodes solution. Stock solutions of $10 \mathrm{~mm}$ amiloride were prepared after dissolving amiloride in a few drops of DMSO. The stock solution was diluted with Tyrodes solution to a final concentration of 0.01-100 $\mu \mathrm{M}$ amiloride. The dose-response relationship for amiloride inhibition was determined in both adult and neonatal rat taste cells by stepwise increases in amiloride concentration. The dose-response curves were fitted with least squares, and the amiloride inhibition constant $\left(K_{\mathrm{i}}\right)$ was calculated. A concentration of $30 \mu \mathrm{M}$ amiloride resulted in maximal blockade of amiloride-sensitive $\mathrm{Na}^{+}$currents in both adult (Doolin and Gilbertson, 1996) and neonatal rats (see Fig. 5). This maximal concentration was used to compare the density of amiloride-sensitive $\mathrm{Na}^{+}$ channels among different age groups.

Staining of presumptive taste pores. Chloromethyl-fluorescein-diacetate (CMFDA) staining was used to determine the number of open and closed pores on tongues at different ages. The tongues were placed in Tyrodes solution containing $2 \mu \mathrm{M}$ CMFDA (Molecular Probes) during enzyme incubation. After staining for $0.5 \mathrm{hr}$, tongues were examined under a Nikon microscope with fluorescein isothiocyanate epifluorescent illumination. The surface of the tongue was scanned with a $20-40 \times$ objective to determine the number and the status of the papillae and their pores. Papillae with presumptive open pores appeared as dark openings in the middle of the papillae, whereas papillae with closed pores were homogeneously covered by labeled epithelial cells without an apparent opening (see Fig. 6).

\section{RESULTS}

A total of 150 successful recordings were obtained. Taste buds could be isolated reliably from the epithelium at PND2. Taste buds isolated from young animals (PND2-5) were considerably smaller in size compared with buds obtained from older animals (Fig. 1). Although we did not determine quantitatively the number of taste cells within individual buds at different ages, the size difference appeared to be attributable to fewer cells in each taste bud from younger animals. This is consistent with earlier reports of vallate taste buds (Hoseley and Oakley, 1987). We investigated whether changes in taste cell size would also contribute to this structural difference. Single taste cells could undergo an increase in size and membrane surface area during development, which would reflect a structural maturation of individual taste cells. Gigaseal whole-cell recordings enabled us to determine the surface area of individual taste cells by measuring their capacitance. Electrode capacitance was minimized by coating the electrode shaft with dental wax and electronically compensating for stray capacitance before obtaining a whole-cell recording. As shown in Figure 2, capacitance did not differ significantly among the various age groups; average capacitances ranged between 12 and 28 $\mathrm{pF}$, which corresponds to a surface area of 1200 to $2800 \mu \mathrm{m}^{2}$ (ANOVA, $p>0.1$ ). This suggests that taste cells reach their mature size long before the taste bud has reached its maximum number of cells.

\section{Development of voltage-gated currents}

Electrophysiological recordings demonstrated that taste cells possess voltage-dependent inward $\mathrm{Na}^{+}$and outward $\mathrm{K}^{+}$currents from early developmental stages. As shown in Figure $3 A$, approximately half of the cells with voltage-gated currents in the age group PND2-4 had both voltage-dependent inward and outward currents, whereas the other half possessed only outward currents. This distribution did not differ significantly from cells of older age groups or adults (ANOVA, inward and outward current, outward current, $p>0.1$ ). In addition, the ratio of cells with voltage-gated currents to the cells without currents remained approximately the same during development, suggesting that the ratio of taste cells to nontaste cells (presumably stem cells) remains constant during development (Table 1). Voltage-dependent currents in taste cells from young animals were indistinguishable from those taste cells of older animals, both in magnitude and in time course (Fig. $3 B, C$; Table 1 ). This suggests that taste cells possess adult-like 

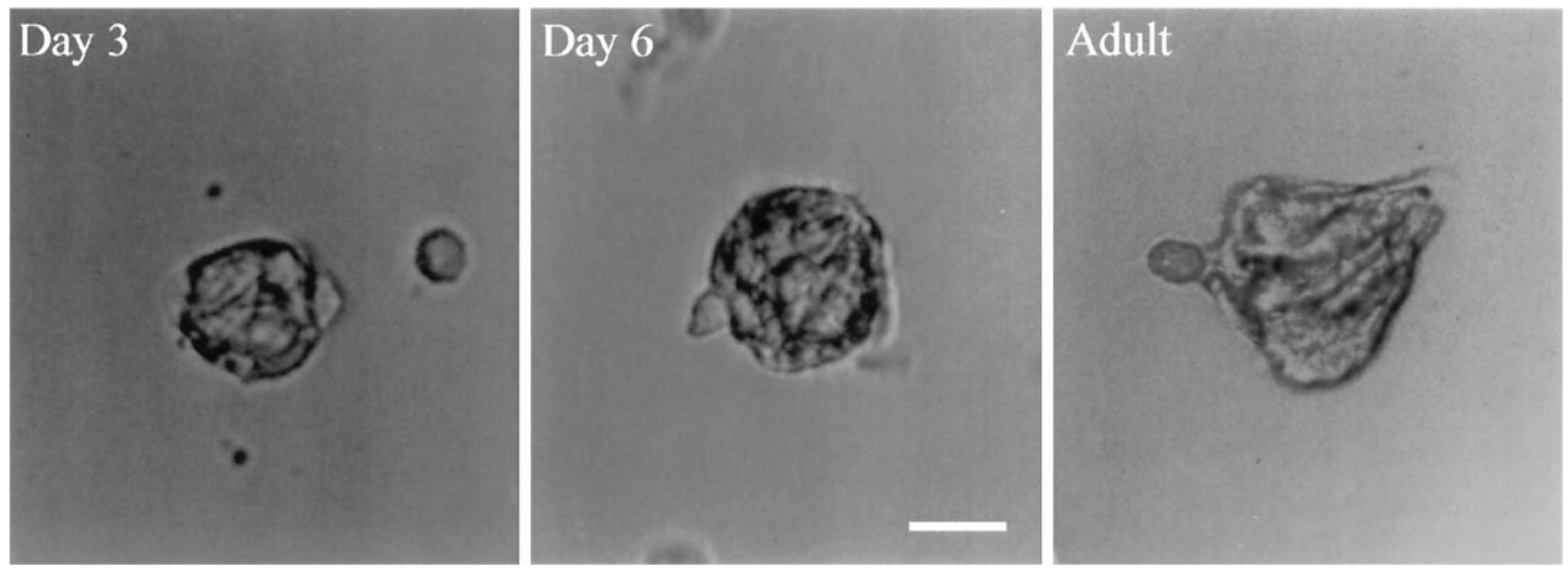

Figure 1. Development of fungiform taste buds. Micrographs depicting taste buds from fungiform papillae derived from different postnatal ages. Taste buds increase in size during development, which is most likely attributable to an increase in the number of cells per bud. Scale bar, $25 \mu \mathrm{m}$.

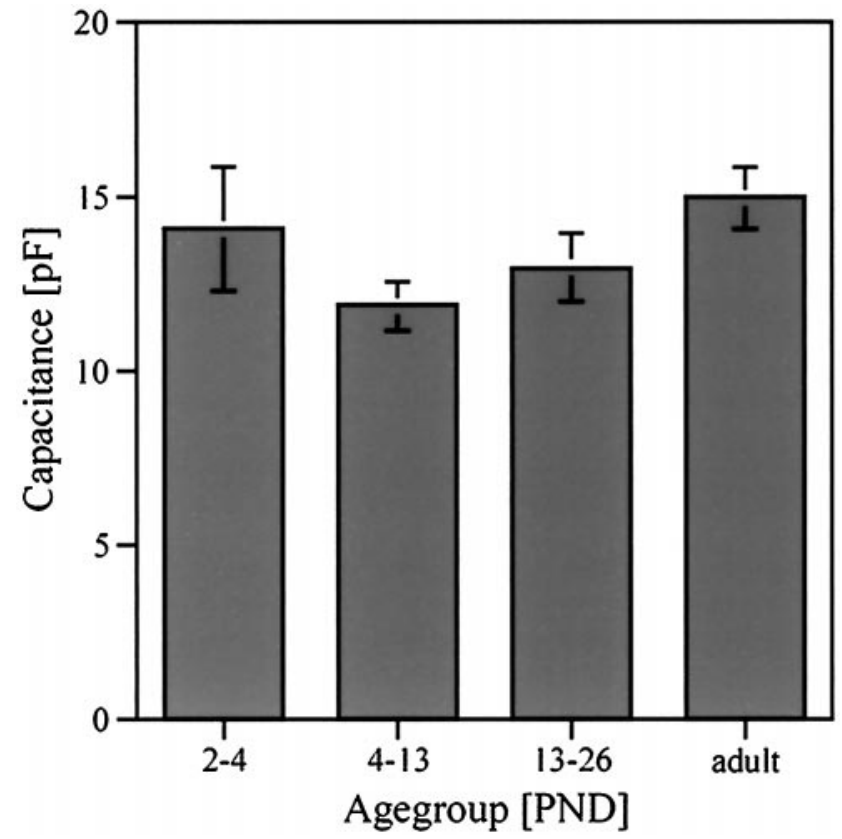

Figure 2. Membrane capacitance of individual taste cells at different ages as a measurement for membrane surface area. Cells were grouped into four different age classes, and capacitance measurements were averaged within each group. There was no significant change in capacitance and, therefore, membrane surface area of single fungiform taste cells during development ( $n=21 / 54 / 33 / 8$; error bars represent SEM).

membrane properties early and that taste cells from early neonatal rats are capable of generating action potentials necessary for release of transmitter and activation of postsynaptic afferent nerve fibers.

\section{Development of amiloride sensitivity}

Passive flux of $\mathrm{Na}^{+}$through amiloride-sensitive $\mathrm{Na}^{+}$channels plays an important role in $\mathrm{Na}^{+}$salt transduction (Heck et al., 1984; Avenet and Lindemann, 1988; Doolin and Gilbertson, 1996). Recordings from chorda tympani afferent nerves have shown that amiloride-sensitive $\mathrm{NaCl}$ responses do not develop before PND8-12 (Hill and Bour, 1985; Sollars and Bernstein,
1994), suggesting indirectly that young taste cells lack functional amiloride-sensitive $\mathrm{Na}^{+}$channels. Using isolated taste buds from rats of different ages, we tested directly for the presence of amiloride-sensitive $\mathrm{Na}^{+}$channels in taste cells. Surprisingly, amiloride-sensitive $\mathrm{Na}^{+}$channels were found in taste buds isolated at PND2. Fifty-four percent of cells in the age group between PND2 and PND4 had amiloride-sensitive responses, with a reduction in holding current and input resistance in response to bath application of amiloride. This percentage did not change significantly at later developmental stages ( $\chi$-square, $p>$ 0.05 ) (Fig. 4). Amiloride-sensitive responses were observed in cells displaying voltage-dependent inward $\mathrm{Na}^{+}$and outward $\mathrm{K}^{+}$ currents as well as in cells with only outward $\mathrm{K}^{+}$currents. We also measured a characteristic reduction in holding current in response to amiloride from 3 cells that did not show any voltagedependent currents. Because taste cells sometimes lose their voltage-gated currents after a long period of recording, these cells likely represent taste cells that originally possessed these membrane currents. To characterize the amiloride-sensitive $\mathrm{Na}^{+}$currents more fully, we compared the response to amiloride with the response obtained by replacement of $\mathrm{Na}^{+}$in the bath with NMDG, a large cation that should not permeate amiloridesensitive $\mathrm{Na}^{+}$channels. The current reduction caused by amiloride was on average 42 and $35 \%$ of the NMDG response for the group of young $(<14 \mathrm{~d})$ and mature animals $(>14 \mathrm{~d})$, respectively. The reduction in current caused by amiloride or NMDG was indistinguishable between young and older animals (Table 1). To obtain a more accurate estimate of the actual current densities and, therefore, the density of amiloride-sensitive $\mathrm{Na}^{+}$channels, the decrease in current after application of amiloride and NMDG was normalized with the capacitance, an indirect measure of membrane surface area. Of importance, the current reduction by amiloride normalized with cell size did not change between taste cells from young $(<14 \mathrm{~d})$ and older $(<14 \mathrm{~d})$ animals $(t$ test, $p>$ 0.2 ). This strongly suggests that the number of amiloride-sensitive $\mathrm{Na}^{+}$channels does not differ significantly between young and older ages.

An important question is whether the amiloride-sensitive $\mathrm{Na}^{+}$ channels in young animals are of the same type as the amiloridesensitive channels in older animals. Amiloride-sensitive channels with a $K_{\mathrm{i}}$ of $50 \mu \mathrm{M}$ have been reported to be present on the 
A
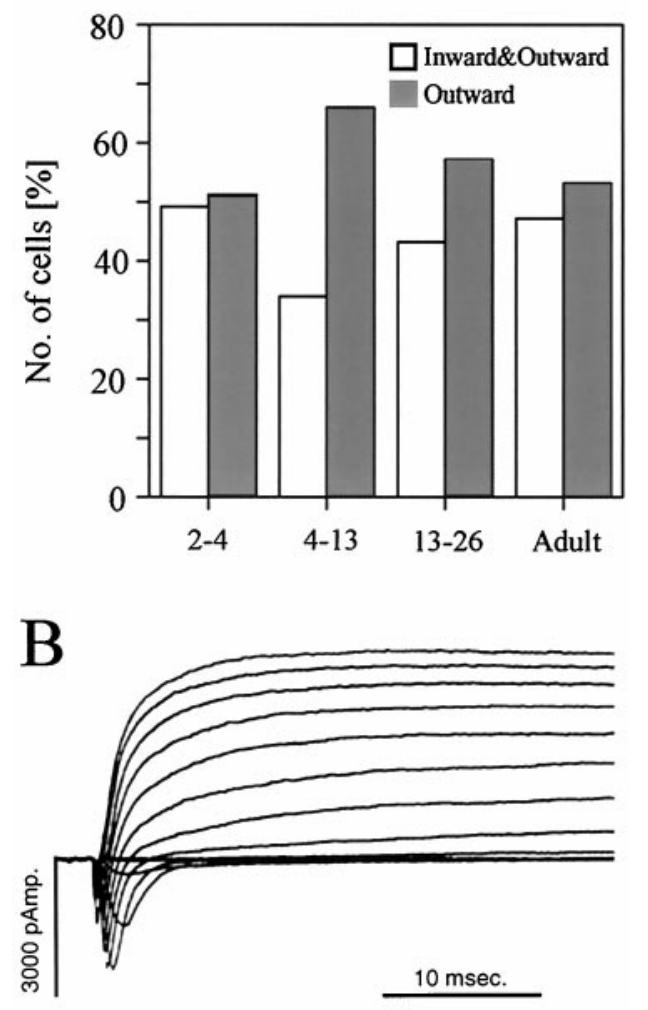

$\mathrm{C}$

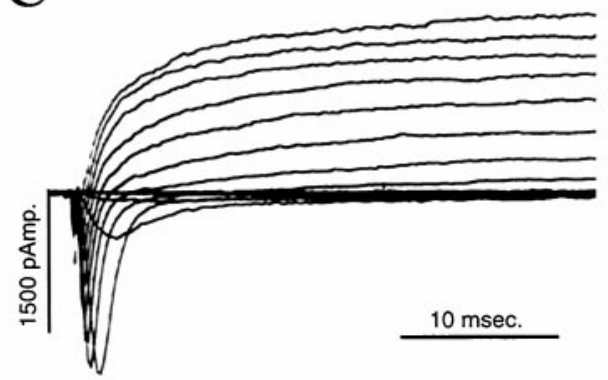

Figure 3. Development of voltage-gated currents in taste cells. Cells with voltage-gated inward and outward currents or voltage-gated outward currents alone are present from PND2-4. A, The percentage of cells with active inward and outward currents or outward currents only does not change significantly with the age of the animals ( $n$ for the four age groups: I\&O-currents, $n=23 / 42 / 25 / 16$; O-currents, $n=22 / 22 / 19 / 14$; error bars represent SEM). $B, C$, Typical examples for currents measured in a 4-d-old $(B)$ and an adult $(C)$ animal.

basolateral membranes of lingual epithelial cells (Mierson et al., 1996), and similar channels may reside in the taste cells of young animals. To examine whether the amiloride-sensitive $\mathrm{Na}^{+}$channels in taste cells of young and mature animals are of the same subtype, we determined the dose-response relationship for amiloride inhibition. Stepwise concentrations of amiloride ranging from 0.01 to $30 \mu \mathrm{M}$ caused subsequent decreases in holding current and membrane conductance in taste cells isolated from both young (PND4-7) and mature rats. The maximal effect of amiloride occurred at concentrations from 10 to $30 \mu \mathrm{M}$. Normalized dose-response curves from young $(n=7)$ and mature taste cells $(n=5)$ are shown in Figure 5, with $K_{\mathrm{i}}$ values of $\sim 0.1$ and 0.2 $\mu \mathrm{M}$, respectively. There was no significant difference between the two groups. Our data are consistent with a previous report of amiloride sensitivity in taste cells of mature rats (Doolin and Gilbertson, 1996). Most taste cells from young rats (19 of 21) first responded to amiloride at a concentration of 0.01 to $0.05 \mu \mathrm{M}$; however, two cells with a small amiloride effect did not respond until the amiloride concentration reached $5 \mu \mathrm{M}$. Taken together, the results suggest that the amiloride-sensitive $\mathrm{Na}^{+}$channels in taste cells of young and mature rats belong to the same subtype.

In a few cases, we recorded responses to amiloride and NMDG that showed a reversal of the normal polarity of the response, i.e., the cells responded with an increase in holding current (data not shown). These abnormal responses occurred predominantly in taste cells of young rats (PND2-4; $n=6$ ), with only a single cell from an older animal showing the reversed response. Because these responses occurred so infrequently, we did not characterize them further.

\section{Responsiveness related to the development of the taste pore}

An important parameter in the development of the tongue is the opening of the taste pore. This event allows taste stimuli to interact with the taste cells and constitutes an important stage in the development of the lingual epithelium. Therefore, we analyzed the development of taste pores using the fluorescent dye CMFDA. This dye is taken up by cells and trapped in intracellular compartments after cleavage by intracellular esterases. After application of the dye to the entire tongue, unstained dark openings in the middle of the papillae surrounded by stained epithelial cells could be distinguished easily, presumably marking open taste pores (Fig. 6). As depicted in Figure 6, the taste pores undergo striking development in the first 2 weeks postnatally. At PND2, only a few papillae (9\%) of the tongue show an open taste pore. As development progresses, the number of papillae with open pores gradually increases until PND21, when the maximum number of open pores is nearly reached $(90 \%)$. These data are consistent with earlier reports of taste pore maturation (Farbman, 1965; Mistretta, 1971). Furthermore, as has been reported previously (Mistretta, 1971; Farbman and Mbienne, 1991), we found a developmental gradient between the tip and the back of the tongue, with the tip showing on average $10 \%$ more open pores than the back during the first 2 postnatal weeks.

In a few experiments, we attempted to correlate taste cell function with the developmental status of the taste pore from which they were isolated. Removing taste buds from the epithelium usually resulted in a small opening in the epithelium. As expected from the experiments using dye staining, the number of openings was fewer in younger animals compared with older animals, suggesting a correspondence between epithelial holes and open pores. A correlation between the status of the pore and the functional characteristics of the associated taste cells was made in 14 buds. Buds derived from both open and closed pores had voltage-dependent inward and outward currents. Buds containing open taste pores possessed inward currents ( 3 buds, $n=5$ ) and outward currents ( 7 buds, $n=8$ ). Also, buds derived from closed pores had inward ( 1 bud, $n=3$ ) and outward currents (1 bud, $n=1)$. Furthermore, taste cells obtained from both types of pores showed responses to amiloride (open pore: 4 buds, $n=4$; closed pore: 3 buds, $n=3$ ). Although the total number of buds was small, these data suggest that the developmental status of the 
Table 1. Summary of electrophysiological membrane properties from fungiform taste cells in young and old animals

\begin{tabular}{|c|c|c|c|c|c|c|c|c|c|c|}
\hline & \multicolumn{2}{|c|}{$\begin{array}{l}\text { Current/No. cells } \\
(\%)\end{array}$} & \multicolumn{2}{|l|}{ Current size $(\mathrm{pA})$} & \multicolumn{2}{|c|}{ Current $T_{1 / 2}(\mathrm{msec})$} & \multicolumn{2}{|c|}{$\begin{array}{l}\text { Resistance } \\
\text { Reduction (\%) }\end{array}$} & \multicolumn{2}{|c|}{$\begin{array}{l}\text { Current reduction } \\
(\mathrm{pA})\end{array}$} \\
\hline & $\begin{array}{l}\text { Voltage- } \\
\text { gated }\end{array}$ & $\begin{array}{l}\text { No } \\
\text { current }\end{array}$ & Outward current & Inward current & $T_{1 / 2 \mathrm{O} \text {-current }}$ & $\mathrm{T}_{1 / 2 \mathrm{I} \text {-current }}$ & Amiloride & NMDG & Amiloride & NMDG \\
\hline $\begin{array}{l}\text { Age groups } \\
\text { PND }<14\end{array}$ & 35 & 13 & $\begin{array}{l}1277 \pm 180 \\
(n=53)\end{array}$ & $\begin{array}{l}792 \pm 142 \\
(n=46)\end{array}$ & $\begin{array}{r}4 \pm 0.5 \\
(n=24)\end{array}$ & $\begin{array}{l}0.5 \pm 0.05 \\
(n=23)\end{array}$ & $69 \%$ & $84 \%$ & $\begin{array}{l}37 \pm 9.6 \\
(n=26)\end{array}$ & $\begin{array}{r}88 \pm 31 \\
(n=22)\end{array}$ \\
\hline $\begin{array}{l}\text { Age groups } \\
\text { PND > } 14\end{array}$ & 42 & 6 & $\begin{array}{l}1012 \pm 146 \\
(n=53) \\
\mathrm{p}>0.1(t \text { test })\end{array}$ & $\begin{array}{l}627 \pm 111 \\
(n=42) \\
\mathrm{p}>0.1(t \text { test })\end{array}$ & $\begin{array}{l}5.2 \pm 0.4 \\
(n=23) \\
\mathrm{p}>0.1 \\
\quad(t \text { test })\end{array}$ & $\begin{array}{l}0.6 \pm 0.05 \\
(n=18) \\
\mathrm{p}>0.1 \\
\quad(t \text { test })\end{array}$ & $72 \%$ & $79 \%$ & $\begin{array}{l}44 \pm 11 \\
(n=15) \\
\mathrm{p}>0.1 \\
\quad(t \text { test })\end{array}$ & $\begin{array}{l}126 \pm 65 \\
(n=14) \\
\mathrm{p}>0.1 \\
\quad(t \text { test })\end{array}$ \\
\hline
\end{tabular}

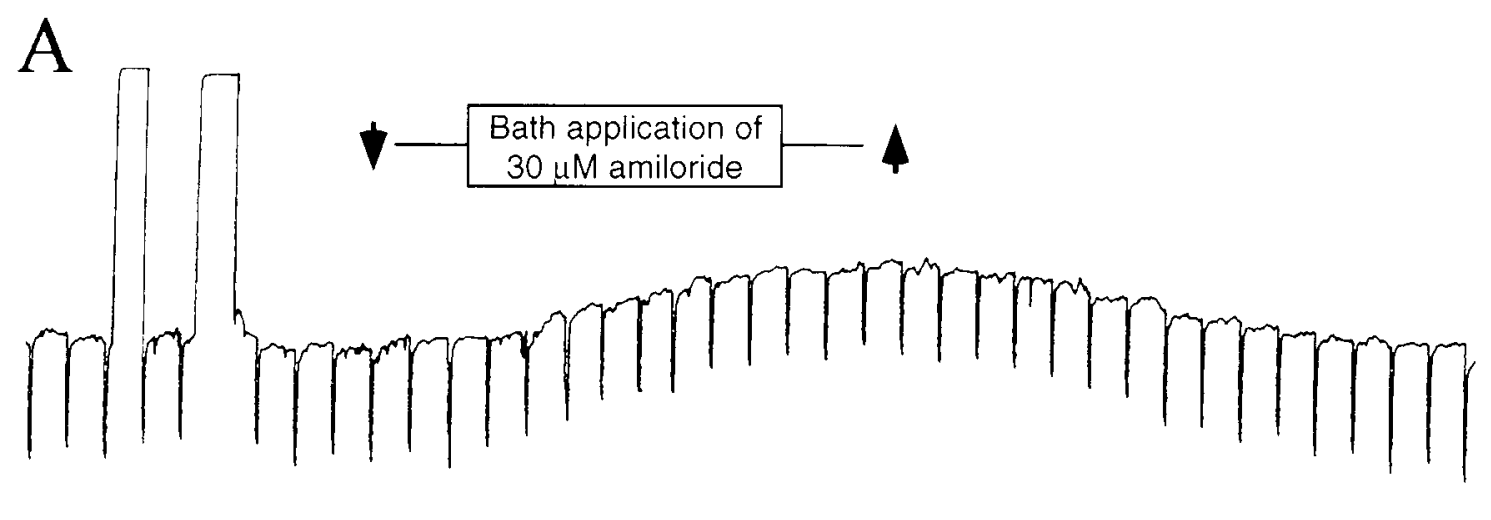

$\mathrm{B}$
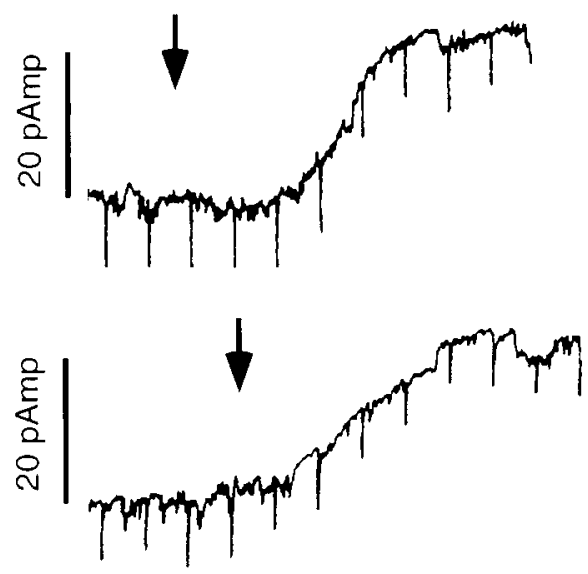

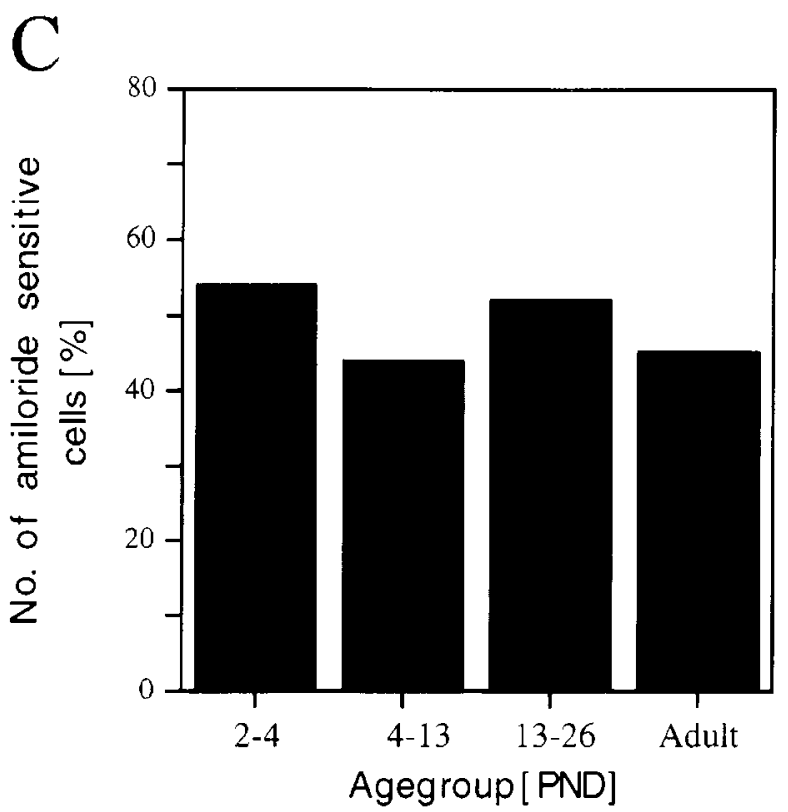

Figure 4. Amiloride sensitivity of fungiform taste cells is present at very young postnatal ages. $A$, A typical response to bath application of $30 \mu \mathrm{M}$ amiloride in a taste cell from a 2-d-old animal. Scale bar, $0.5 \mathrm{~min}$. The cell responded with a decrease in inward holding current and a decrease in input resistance. $B$, Two representative and indistinguishable responses to amiloride from a 2-d-old (top trace) and an adult animal (bottom trace). $C$, Taste cells that responded to the application of amiloride (arrows) were found at all ages. Surprisingly, the percentage of taste cells with amiloride-sensitive currents does not increase during development ( $n$ for four age groups: 28/43/27/16). 

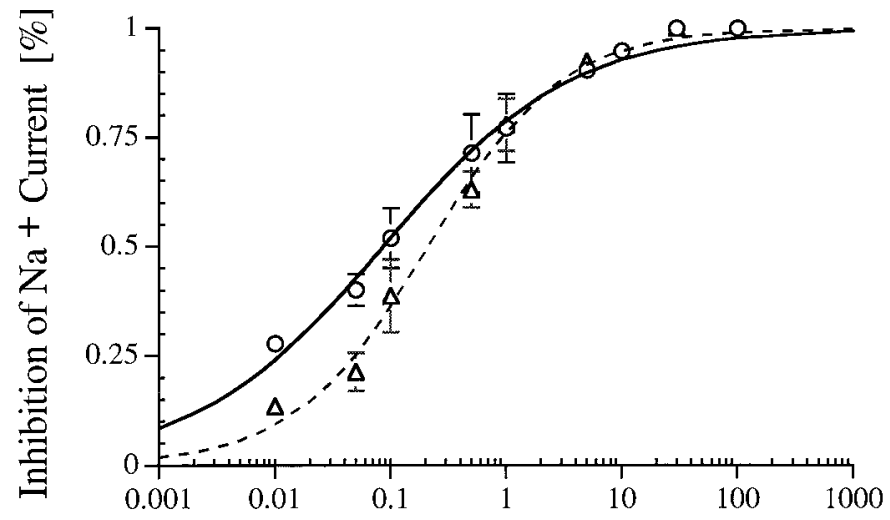

Amiloride $[\mu \mathrm{M}]$

Figure 5. Dose-response curves for amiloride-sensitive $\mathrm{Na}^{+}$currents in young and adult animals. Curves are fitted with the least-squares equation. Amiloride inhibition constants in young (solid line) and mature (dotted line) rat taste cells are $\sim 0.1$ and $0.2 \mu \mathrm{M}$, respectively. Error bars represent mean \pm SEM.

taste pore is not directly correlated with the physiological properties measured in our experiments.

\section{DISCUSSION}

In the present study, we used gigaseal whole-cell recordings to examine the membrane properties of rat fungiform taste cells during development. The main finding of this study is that taste cells isolated from early postnatal rat tongues exhibited all of the basic electrophysiological properties present in adult animals. Voltage-sensitive $\mathrm{Na}^{+}$and $\mathrm{K}^{+}$currents were found as early as PND2. These findings suggest that taste cells from very young rats are capable of generating action potentials, which should result in signaling to the afferent nerve. Both the percentage of cells with voltage-sensitive $\mathrm{Na}^{+}$currents and the size of the currents remained constant throughout development. Furthermore, our data show that amiloride-sensitive $\mathrm{Na}^{+}$channels are present and functional at PND2, when taste buds can first be isolated. Two main differences became evident between taste cells of young and mature rats. One difference was the size of the taste buds, reflecting an increase in the number of cells within each single taste bud (Hosley and Oakley, 1987). The second was the status of their taste pores; during development, papillae undergo a striking change as their pores open.

Fungiform taste cells that respond to $\mathrm{Na}^{+}$salts are characterized by expression of amiloride-sensitive $\mathrm{Na}^{+}$channels. Application of amiloride reduces resting $\mathrm{Na}^{+}$conductance, leading to a reduced holding current (Avenet and Lindemann, 1988; Doolin and Gilbertson, 1996). Therefore, amiloride can be used as a tool to study and characterize the functionality of $\mathrm{Na}^{+}$transduction in taste cells. We found that amiloride sensitivity was already present and developed in taste cells at PND2. The characteristic reduction in holding current with amiloride was observed throughout our experiments. In one set of experiments, however, we occasionally measured responses to amiloride that were reversed. After application of amiloride, these cells showed an increase in membrane current. Most of these cells $(n=6)$ were found in taste buds derived from very young animals (PND2-4). Gilbertson and Zhang (1996) recently showed that amiloridesensitive $\mathrm{Na}^{+}$channels in taste cells can exhibit self-inhibition by
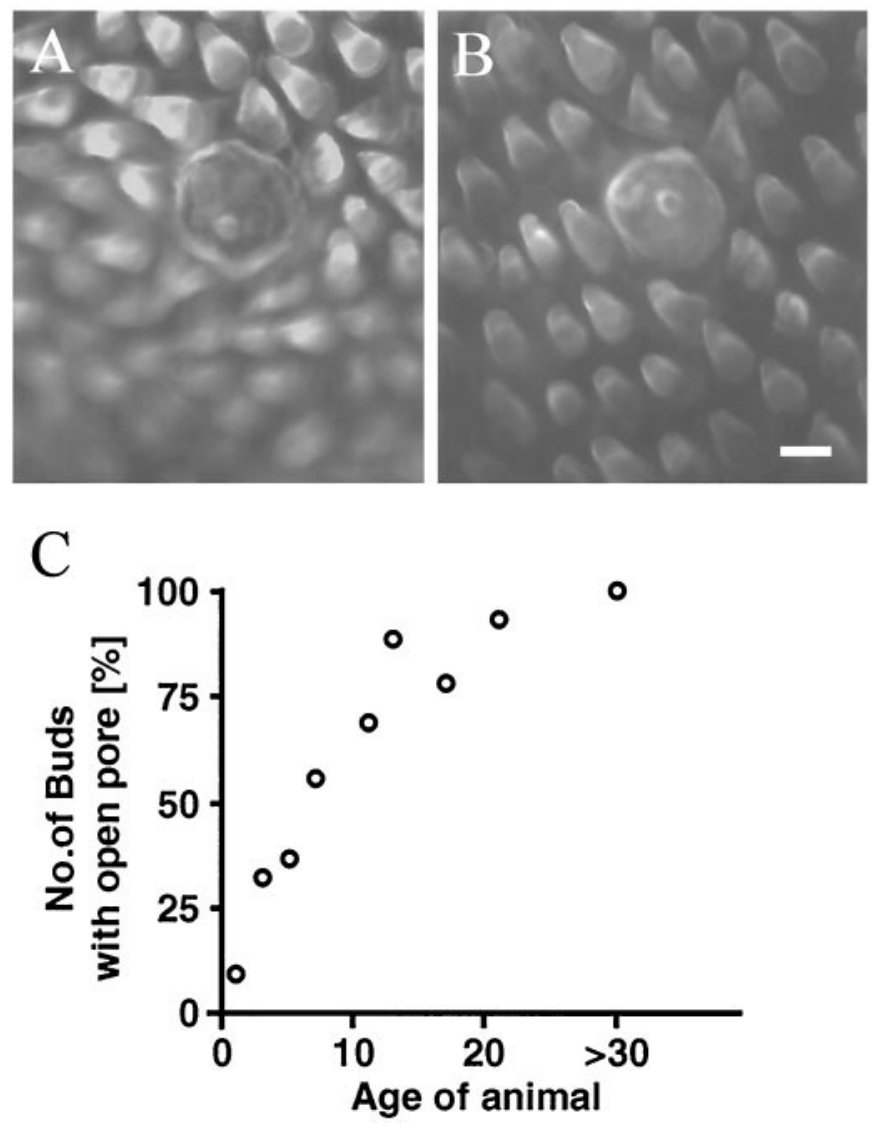

Figure 6. The status of the taste pore in fungiform taste buds during development. The status of the pore was determined from tongues at different ages using a fluorescent stain (see Materials and Methods). Micrographs of papillae in a 6-d-old animal show both closed $(A)$ and open $(B)$ pores. Although epithelial cells covering the surface of the papilla are fluorescently labeled in $A, B$ shows a dark spot in the middle of the papillae, presumably corresponding to the opening of a pore. Scale bar, $25 \mu \mathrm{m}$. $C$, Taste pores undergo a striking change over time. Only $9 \%$ of papillae in 2-d-old animals have an open pore, whereas $100 \%$ of the pores are open in adult animals.

$\mathrm{Na}^{+}$. This $\mathrm{Na}^{+}$self-inhibition becomes apparent as a nonlinear response, with reduced holding currents measured in high $\mathrm{Na}^{+}$ concentrations (>50 mM) and larger currents in lower $\mathrm{Na}^{+}$concentrations. Their results suggest further that the $\mathrm{Na}^{+}$and amiloride binding site are closely linked. This close interaction might explain our finding of an increase in current after application of amiloride in some taste cells from younger animals. A removal of $\mathrm{Na}^{+}$self-inhibition by amiloride in young taste cells, however, remains completely speculative.

The opening of the taste pore constitutes an important step in the development of the papillae. Therefore, we attempted to determine a possible relationship between pore development and differentiation of taste cells as measured by their response properties. Based on a small number of recordings, our data suggest that the opening of the taste pore is not directly correlated with the development of response properties of taste cells. Cells from taste buds containing both open and closed pores possessed voltage-sensitive $\mathrm{Na}^{+}$currents and were sensitive to amiloride, suggesting an early development of these cell properties. These observations also fit previous ultrastructural data, suggesting that mature taste receptor cells appear before opening of the pore 
(Farbman, 1965). However, our data differ from those obtained from amphibian taste cells, in which contact with the taste pore appeared to correlate with the expression of voltage-dependent inward currents (MacKay-Sim et al., 1996).

Previous data from afferent nerve recordings have led to the assumption that the membrane properties responsible for $\mathrm{Na}^{+}$ transduction may not be present in taste cells before PND14 (Hill and Bour, 1985). Our study is the first to provide a direct analysis of the membrane properties of taste cells early in development. Quantitative analysis of the amiloride responses, surprisingly, revealed that the number of amiloride-sensitive cells, the size of the response, and the sensitivity of the cells to amiloride remained the same throughout development. Mierson et al. (1996) suggested the presence of amiloride channels with a lower binding constant $\left(K_{\mathrm{i}}=50 \mathrm{vs} 0.1 \mu \mathrm{M}\right)$ in the basolateral membrane of rat taste cells. The dose-response curve for amiloride in taste buds from young postnatal animals did not reveal the presence of a significant number of these low-affinity amiloride channels. An important characteristic of our experiments is that taste buds have been removed from the surrounding epithelium, thus allowing access of pharmacological agents to both apical and basolateral membranes. In taste cells, as well as other epithelial cells, ion channel composition differs between these membrane compartments (Van Driesche and Zeiske, 1985; Kinnamon et al., 1988; Roper and McBride, 1989). For example, in Necturus taste cells, $\mathrm{K}^{+}$channels are expressed almost exclusively in the apical membrane (Kinnamon et al., 1988). Amiloride-sensitive $\mathrm{Na}^{+}$channels are localized to the apical membrane in many types of epithelial cells (Van Driesche and Zeiske, 1985), but their distribution in taste cells is not clear. Immunocytochemical studies have shown that the channel protein is expressed on apical as well as basolateral membranes of taste cells (Simon et al., 1993; Li et al., 1994; Stewart et al., 1995), but physiological studies are needed to determine whether the basolateral channels are functional. Taste stimuli interact initially with the apical membrane in an intact tongue, so an apical localization would facilitate the transduction process. Although our results indicate that the mean density of amiloride-sensitive $\mathrm{Na}^{+}$channels does not change over time, their distribution within the membrane may be altered. Such a redistribution would remain undetected in whole-cell recordings. Sensitivity to $\mathrm{Na}^{+}$salts and amiloride presumably would not become apparent in the intact tongue before amiloride-sensitive $\mathrm{Na}^{+}$channels become selectively localized in the apical membrane. Previous experiments using the Ussing chamber lend support to this hypothesis (Settles and Mierson, 1993); measurements of current across the lingual epithelium, reflecting the summated activity of many taste buds, show the same late appearance of $\mathrm{Na}^{+}$and amiloride sensitivity (PND $>14$ ) as whole nerve recordings and behavioral experiments. In addition, preliminary experiments using loose patch recordings from taste buds of the intact tongue show that responses to $\mathrm{NaCl}$ are small at early postnatal ages, with amiloride sensitivity not appearing before PND17 (Kinnamon et al., 1995).

The surrounding epithelium is also important to taste cell function. Depending on the status of the taste pore, stimuli may or may not have access to the taste cells. As we (in this study) and others (Mistretta, 1971; Mbiene and Farbman, 1993) have shown, most taste pores are closed in young animals. Only $9 \%$ of the pores appear to be in an open state at PND2, with the number of open pores gradually increasing until most pores are open by the third postnatal week. Closed taste pores may constitute a barrier limiting the access of $\mathrm{Na}^{+}$and amiloride to the taste cells, although Mbiene and Farbman (1993) found that the epithelium covering the taste pore in young neonates is permeable to intercellular tracers. Nonetheless, an increase in the number of taste buds exposed to taste stimuli by the opening of taste pores may be partially responsible for the increase in $\mathrm{Na}^{+}$and amiloride sensitivity observed in previous behavioral and physiological experiments. However, it cannot explain the late onset of amiloride sensitivity that was found in those experiments. This makes it likely that amiloride-sensitive $\mathrm{Na}^{+}$channels are not localized to the apical membrane in young neonates. Further studies will be necessary to determine when amiloride-sensitive $\mathrm{Na}^{+}$channels become localized to the apical membrane of taste cells and how apical-basolateral differentiation is correlated with the opening of the taste pore.

\section{REFERENCES}

Avenet P, Lindemann B (1988) Amiloride-blockable $\mathrm{Na}^{+}$currents in isolated taste receptor cells. J Membr Biol 105:245-255.

Bernstein IL, Courtney L (1987) Salt preferences in the preweanling rat. Dev Psychobiol 20:443-453.

Doolin RE, Gilbertson TA (1996) Distribution and characterization of functional amiloride-sensitive sodium channels in rat tongue. J Gen Physiol 107:545-554.

Farbman AI (1965) Electron microscope study of the developing taste bud in rat fungiform papillae. Dev Biol 11:110-135.

Farbman AI, Mbiene JP (1991) Early development and innervation of taste bud-bearing papillae on the rat tongue. J Comp Neurol 304:172-186.

Ferrell MF, Mistretta CM, Bradley RM (1981) Development of chorda tympani taste responses in rat. J Comp Neurol 198:37-44.

Formaker BK, Hill DL (1990) Alterations of salt taste perception in the developing rat. Behav Neurosci 104:356-364.

Gilbertson TA, Zhang H (1996) Sodium self-inhibition in amiloride sensitive sodium channels: implications for salt taste transduction. Soc Neurosci Abstr 651.4.

Gilbertson TA, Roper SD, Kinnamon SC (1993) Proton currents through amiloride-sensitive $\mathrm{Na}^{+}$channels in isolated hamster taste cells: enhancement by vasopressin and cAMP. Neuron 10:931-942.

Heck GL, Mierson S, DeSimone JA (1984) Salt taste transduction occurs through an amiloride sensitive sodium transport pathway. Science 223:403-405.

Hill DL (1987) Development of amiloride sensitivity in the rat peripheral gustatory system. Ann NY Acad Sci 510:369-372.

Hill DL, Almi CR (1980) Ontogeny of chorda tympani nerve responses to gustatory stimuli in the rat. Brain Res 197:27-38.

Hill DL, Bour TC (1985) Addition of functional amiloride-sensitive components to the receptor membrane: a possible mechanism for altered taste responses during development. Brain Res 352:310-313.

Hill DL, Mistretta CM (1990) Developmental neurobiology of salt taste sensation. Trends Neurosci 13:188-195.

Hill DL, Mistretta CM, Bradley RM (1982) Developmental changes in taste response characteristics of rat single tympani fibers. J Neurosci 2:782-790.

Hosley MA, Oakley B (1987) Postnatal development of the vallate papilla and taste buds in rats. Anat Rec 218:216-222.

Kinnamon SC, Roper SD (1988) Membrane properties of isolated mudpuppy taste cells. J Gen Physiol 91:351-371.

Kinnamon SC, Dionne VE, Beam KG (1988) Apical localization of $\mathrm{K}^{+}$ channels in taste cells provides the basis for sour taste transduction. Proc Natl Acad Sci USA 85:7023-7027.

Kinnamon JC, McPheeters MM, Harris DE, Kinnamon SC (1995) Development of neonatal rat rat taste buds. Chem Senses 20:90.

Li X-J, Blackshaw S, Snyder SH (1994) Expression and localization of amiloride-sensitive sodium channel indicate a role for non-taste cells in taste perception. Proc Natl Acad Sci USA 91:1814-1818.

Lin W, Bottger B, Finger TE, Rossier BC, Kinnamon SC (1997) Immunocytochemical localization of epithelial $\mathrm{Na}^{+}$channel subunits in rat taste cells. Chem Senses, in press.

Lindemann B, Barbry P, Kretz O, Bock R (1997) Salty and sweet transduction. Chem Senses, in press.

MacKay-Sim A, Delay RJ, Roper SD, Kinnamon SC (1996) Develop- 
ment of voltage-dependent currents in taste receptor cells. J Comp Neurol 365:278-288.

Mbiene JP, Farbman AI (1993) Evidence for stimulus access to taste cells and nerves during development: an electron microscopic study. Microsc Res Technique 26:94-105.

McPheeters M, Kinnamon JC, Kinnamon SC (1994) Amiloridesensitive $\mathrm{Na}^{+}$currents in taste cells isolated from neonatal rats. Chem Senses 19:518.

Mierson S, Olson MM, Tietz AE (1996) Basolateral amiloride-sensitive $\mathrm{Na}^{+}$transport pathway in rat tongue epithelium. J Neurophysiol 76:1297-1309.

Mistretta CM (1971) Permeability of tongue epithelium and its relation to taste. Am J Physiol 220:1162-1167.

Moe KE (1986) The ontogeny of salt preference in rats. Dev Psychobiol 19:185-196.

Roper SD (1983) Regenerative impulses in taste cells. Science 220:1311-1312.

Roper SD, McBride Jr DW (1989) Distribution of ion channels on taste cells and its relationship to chemosensory transduction. J Membr Biol 109:29-39.

Settles AM, Mierson S (1993) Ion transport in rat tongue epithelium in vitro: a developmental study. Pharmacol Biochem Behav 46:83-88.

Simon SA, Holland VF, Benos DJ, Zampighi GA (1993) Transcellular and paracellular pathways in lingual epithelia and their influence in taste transduction. Microsc Res Technique 26:196-208.

Sollars SI, Bernstein IL (1994) Amiloride sensitivity in the neonatal rat. Behav Neurosci 108:981-987.

Stewart RE, Hill DL (1992) Immunohistochemical evidence for the presence of amiloride-sensitive sodium channels in the tastebuds of sodium-restricted rats. Chem Senses 17:704.

Stewart RE, Lasiter PS, Benos DJ, Hill DL (1995) Immunohistochemical correlates of peripheral gustatory sensitivity to sodium and amiloride. Acta Anatomica 153:310-319.

Van Driessche W, Zeiske W (1985) Ionic channels in epithelial cell membranes. Physiol Rev 65:833-903. 